\title{
A COMPARISON OF THE DIVERSITY AND ABUNDANCE OF BRACONIDAE (HYMENOPTERA: ICHNEUMONOIDEA) IN THREE HIGHLANDS OF PENINSULAR MALAYSIA
}

\author{
Norliyana H. A. and A. B. Idris* \\ School of Environmental and Natural Resource Sciences, Faculty of Science and Technology, Universiti \\ Kebangsaan Malaysia, 43600 UKM Bangi, Malaysia \\ *idrisgh@ukm.my (Corresponding author) \\ Received on 2nd Feb 2010, accepted in revised form 24th November 2011.
}

\begin{abstract}
A study on the abundance and diversity of Braconidae at Bukit Larut, Perak (BL), Cameron Highland, Pahang $(\mathrm{CH})$ and Gunung Ledang, Johor (GL) was conducted from $13^{\text {th }}$ October 2006 to $17^{\text {th }}$ December 2006 using Malaise traps. A total of 57 individuals of Braconidae were successfully collected comprising of 12 subfamilies and 36 species. Braconids were most abundantly found in BL with 22 individuals, comprising of 15 individuals ( 8 subfamilies and 13 species) in upper part $(600-900 \mathrm{~m})$ and seven individuals $(6$ subfamilies and 7 species) in lower part (200-500 m) of the highland. Shannon-Weiner Index for divesrsity (H') showed that there was no significant different $(\mathrm{P}>0.05)$ in species diversity between sites, with BL having the highest diversity value $\left(\mathrm{H}^{\prime}=2.84\right)$, followed by $\mathrm{GL}\left(\mathrm{H}^{\prime}=2.75\right)$ and $\mathrm{CH}\left(\mathrm{H}^{\prime}=2.66\right)$. Species similarity between sites were low, ranging from $10 \%$ to $20 \%$ indicating great differences in biological and environmental factors between sites that influencing the fauna of Braconidae at these highlands. This study also shows that braconid wasps was more abundant in the undisturbed highland (BL) compared to the disturbed highland (CH and GL).
\end{abstract}

\begin{abstract}
ABSTRAK Kajian kelimpahan dan kepelbagaian Braconidae di Bukit Larut (BL), Cameron Highland (CH) dan Gunung Ledang (GL) telah dijalankan dari 13 Oktober 2006 hingga 17 Disember 2006 dengan menggunakan perangkap Malaise. Sebanyak 57 individu Braconidae telah berjaya dikumpulkan, terdiri dari 12 subfamili dan 36 spesies. Braconidae ditemui amat melimpah di BL dengan 22 individu, merangkumi 15 individu (8 subfamili dan 13 spesies) di aras atas tanah tinggi BL (600-900 m) dan 7 individu (6 subfamili dan 7 spesies) di aras bawah tanah tinggi BL (200-500 m). Index kepelbagaian Shanon-Weiner (H') menunjukkan bahawa tiada perbezaan yang signifikan $(\mathrm{p}>0.05)$ dalam kepelbagaian spesies, dengan BL memperoleh jumlah kepelbagaian tertinggi $\left(H^{\prime}=2.84\right)$, diikuti oleh $\mathrm{GL}\left(\mathrm{H}^{\prime}=2.75\right)$ dan $\mathrm{CH}\left(\mathrm{H}^{\prime}=2.66\right)$. Persamaan spesies antara kawasan adalah rendah, iaitu dalam julat $10 \%$ ke 20\%, menunjukkan terdapat perbezaan biologi dan persekitaran antara kawasan kajian yang mempengaruhi fauna Braconidae di ketiga-tiga kawasan tanah tinggi ini. Kajian ini juga menunjukkan bahawa Braconidae lebih melimpah di kawasan yang kurang atau tidak terganggu (BL) berbanding kawasan yang terganggu ( $\mathrm{CH}$ dan $\mathrm{GL})$.
\end{abstract}

(Key words: Braconidae, Hymenoptera, Diversity, Cameron Highland, Bukit Larut, Gunung Ledang)

\section{INTRODUCTION}

Hymenoptera is the most diverse Order in insect family, after Coleoptera and Lepidoptera (Askew 1973). Hymenoptera represent about $20 \%$ of insects in the world and the total species comprising about twice the total of all terestrial and aquatic vertebrate. Morphologically, Hymenoptera has rigid, hard and small to medium size of body, and narrow waist between thoraxs and abdomen. Most hymenopterans have one or two pairs of simple venation of membraneous wing. They also have small hind wing compared to the forewing (Goulet 1993).

Braconidae is one of the family under Hymenoptera, which also belongs to the superfamily of Ichneumonoidea. It has been known 
as the second largest family in Hymenoptera (Sharkey 1993a). Braconidae are diverse and most abundance, with approximately 40,000 species worldwide and can be found in various habitats. Braconidae is important due to its potential as a biological control agent of insect pest of agricultural crop and forest trees. They were also known as parasitoid, which killed other insects such as the larvae of Coleoptera, Lepidoptera and Diptera.

Bukit Larut Perak, Gunung Ledang Johor and Cameron Highland Pahang are few areas in Malaysia where are known as location for ecotourism. However, there have been activities like illegal clearing and agriculture occuring at this sites, as such it is affecting the insect diversity. The objective of the study was to test the hypothesis that there is a differences in the Braconidae diversity and abundance between these highlands.

\section{MATERIALS AND METHODS}

The Gunung Ledang (GL), Bukit Larut (BL) and Cameron Highland $(\mathrm{CH})$ in the state of Johor, Perak and Pahang, respectively, were selected for the study sites. A total of 36 Malaise Trap (Townes 1972) was used in sampling in which 18 were installed on the upper part of the hill while the other 18 were installed at the lower part of the hill, making it 12 traps per sites (treatments). Insect sampled was collected every week started from October 13 to December 17, 2006.

All collected samples were taken to laboratory for sorting, pinning, drying, labeling and identifying. Insects were identified using stereo microscope at 100x magnification and number of individual per site were recorded. Insect diversity were analysed by using Shanon-Weiner Index (H') from BIODAP programme. Difference in means abundance among sites were analysed using two-way ANOVA. When ANOVA result significant, Tukey's honest significance (HSD) test was used to find different among the means.

\section{RESULTS AND DISCUSSION}

A total of 57 individuals of Braconidae, represent 12 subfamilies and 36 species (morfospecies) were successfully collected from Bukit Larut Perak (BL), Gunung Ledang Johor (GL) and Cameron Highland Pahang $(\mathrm{CH})$ (Table 1). In general, BL had the riches number of species and highest abundant (of individual) compared to GL and $\mathrm{CH}$.
A total of 12 subfamilies recorded in this study representing about $41.4 \%$ of the 29 subfamilies recorded all over the world (Sharkey 1993b). There are six subfamilies that have been found in all studied area namely the Rogadinae, Gnamptodontinae, Doryctinae, Opiinae, Alysiinae and Cardiochilinae.

The BL and GL had the highest and lowest number of braconid individuals respectively (Table 1). This is not surprising as BL had higher density of plants compared to CH and GL (Latiff, A. M., 2010). Higher density of plants can contribute higher humidity in that forest than in less plant density forest.

The importance of plants is just like a sponge to absorb water. Humidity is important for parasitoid to live as the life-spend of parasitoid increases when the humidity increase (Szujecki, 1987). In addition, BL is known as the most wet area in Peninsular Malaysia, because the area receiving rain almost everyday which contributed to higher humidity in that area than the surrounding areas (Azmariah, 2001).

The GL had the lowest number of individuals because it had relatively less flora and most importantly it being surrounded by homogen plantation or one type plantation (oil palm) compared to BL. Nevetherless, the $\mathrm{CH}$ had as low individual abundance as GL. The $\mathrm{CH}$ is surrounded by various agriculture areas like tea plantation, cabbage, roses and tomatoes farms.

The highest $\mathrm{H}^{\prime}$ value is obtained from $\mathrm{BL}\left(\mathrm{H}^{\prime}=\right.$ $2.84)$, followed by $\mathrm{GL}\left(\mathrm{H}^{\prime}=2.75\right)$ and $\mathrm{CH}$ $\left(\mathrm{H}^{\prime}=2.66\right)$ (Table 2). There was a significant $(\mathrm{t}=$ $1.754, \mathrm{df}=40, \mathrm{p}<0.05)$ difference between $\mathrm{H}^{\prime}$ of $\mathrm{BL}$ and $\mathrm{CH}$, indicating $\mathrm{BL}$ had been significantly less disturbed than $\mathrm{CH}$. This result is congruent with Idris (2003) who found that the decreased of the habitat size will negatively affecting the population existence of Braconidae.

This is because the diversity and abundance of Braconidae was highly responsive to environment and habitat changes (Kim, 1993; Forman, 1995; Gauld, 1984). Simlarly, the GL had H' different significantly with $\mathrm{BL}(\mathrm{t}=1.003, \mathrm{df}=38, \mathrm{p}<0.05)$ but was not with $\mathrm{CH}(\mathrm{P}>0.05)$. High braconid diversity (H') at BL seemed to be due high species richness ( $R^{\prime}$ ) and evenness (E') in BL (Pielou 1975). In contrast, the $H^{\prime}$ value of $\mathrm{CH}$ is low because of low R' and E values. 
Table 1. Number of Subfamilies and individuals of Braconidae from three highlands of Peninsular Malaysia ${ }^{1,}$

\begin{tabular}{lccccc}
\hline Subfamily & Species & BL & CH & GL & $\begin{array}{c}\text { No. Of } \\
\text { individual per } \\
\text { subfamily }\end{array}$ \\
\hline Rogadinae & 7 & $7(5)$ & $7(4)$ & $5(4)$ & 19 \\
Microgastrinae & 3 & $2(1)$ & 0 & $3(3)$ & 5 \\
Ichneutinae & 2 & 0 & 0 & $2(2)$ & 2 \\
Gnamptodontinae & 5 & $3(3)$ & $2(2)$ & $2(2)$ & 7 \\
Doryctinae & 4 & $1(1)$ & $2(2)$ & $2(2)$ & 5 \\
Opiinae & 3 & $3(2)$ & $2(2)$ & $1(1)$ & 6 \\
Alysiinae & 4 & $1(1)$ & $2(2)$ & $1(1)$ & 4 \\
Cardiochilinae & 3 & $1(1)$ & $2(2)$ & $1(1)$ & 4 \\
Apozyginae & 2 & $1(1)$ & $1(1)$ & 0 & 2 \\
Macrocentrinae & 1 & $1(1)$ & 0 & 0 & 1 \\
Khoikhoiinae & 1 & $1(1)$ & 0 & 0 & 1 \\
Miracinae & 1 & $1(1)$ & 0 & 0 & 1 \\
\hline Total Individual & - & $\mathbf{2 2}$ & $\mathbf{1 8}$ & $\mathbf{1 7}$ & $\mathbf{5 7}$ \\
Total subfamily & $\mathbf{1 1}$ & $\mathbf{7}$ & $\mathbf{8}$ & - \\
Total species & $\mathbf{3 6}$ & $\mathbf{1 8}$ & $\mathbf{1 5}$ & $\mathbf{1 6}$ & - \\
\hline
\end{tabular}

${ }^{1}$ in bracket is the number of species; ${ }^{2} \mathrm{BL}$, Bukit Larut; $\mathrm{CH}$, Cameron Highland; GL. Gunung Ledang

Table 2. Shanon-Weiner Diversity Index (H'), Shannon Evenness Index (E') and Margelef Index (R') for Braconidae which is found at Bukit Larut Perak (BL), Cameron Highland Pahang $(\mathrm{CH})$ and Gunung Ledang Johor (GL)*

\begin{tabular}{cccc}
\hline Area & H' $^{\prime}$ & E' $^{\prime}$ & $\mathrm{R}^{\prime}$ \\
\hline BL & $2.84 \mathrm{a}$ & 0.98 & 5.50 \\
$\mathrm{CH}$ & $2.66 \mathrm{~b}$ & 0.98 & 4.84 \\
$\mathrm{GL}$ & $2.75 \mathrm{~b}$ & 0.99 & 5.29 \\
\hline
\end{tabular}

\footnotetext{
*In column, values of H' with similar letter are not significantly different $(\mathrm{t}=$ test, $\mathrm{P}<0.05)$
}

The H', E' and R' values were varied between upper and lower levels of the three highlands (Figure 1). In BL, H' and R' value for upper BL [600 - $900 \mathrm{~m}$ above sea level (asl)] was higher $\left(\mathrm{H}^{\prime}\right.$ $\left.=2.52, \mathrm{R}^{\prime}=4.43\right)$ compared to lower BL $(200-$ $500 \mathrm{~m}$ asl $)\left(\mathrm{H}^{\prime}=1.95, \mathrm{R}^{\prime}=3.08\right)$, but the $\mathrm{E}^{\prime}$ value is higher in lower $\mathrm{BL}\left(\mathrm{E}^{\prime}=1.00\right)$ compared to upper BL $\left(E^{\prime}=0.98\right)$. Similar trend showed for GL where the upper GL had higher H' and R' values $\left(H^{\prime}=\right.$ $\left.2.46, \mathrm{R}^{\prime}=4.29\right)$ compared to lower GL $\left(\mathrm{H}^{\prime}=1.39\right.$, $\left.R^{\prime}=2.16\right)$. Whilst, the E' value for upper (0.99) and lower (1.00) GL was somewhat similar. However, the $\mathrm{H}^{\prime}$ and $\mathrm{R}$ ' values were higher in lower $\mathrm{CH}\left(\mathrm{H}^{\prime}=2.25, \mathrm{R}^{\prime}=3.62\right)$ compared to upper $\mathrm{CH}\left(\mathrm{H}^{\prime}=1.79, \mathrm{R}^{\prime}=2.79\right)$, while the $\mathrm{E}^{\prime}$ value for upper $\mathrm{CH}$ was higher (1.00) compared to lower E' (0.98). May (1975) said that H' value in range 0 to 2.5 is considered as low for species diversity. Therefore, these three highlands could still be said of having high diversity of braconid fauna. In general, braconid is relatively more diverse in upper than lower levels of the highlands in the tropical areas (Gauld 1986) except for the $\mathrm{CH}$. This low $\mathrm{H}^{\prime}$ value at upper levels of $\mathrm{CH}$ indicates that alot of disturbances have occurred on the upper levels of $\mathrm{CH}$ which affected the braconid survival, most probably due to illegal clearing for vegetables and flower growing. 


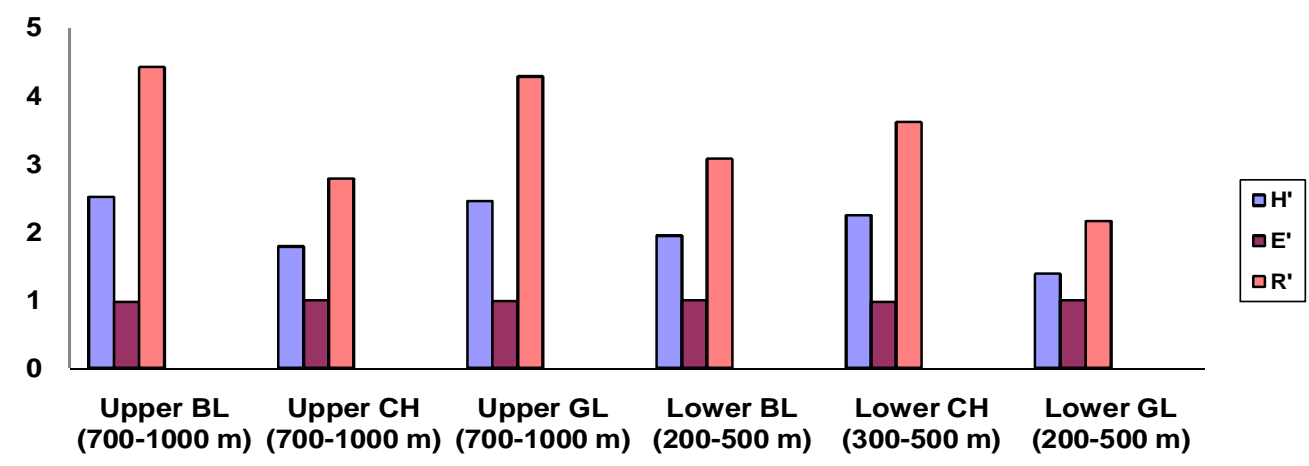

Figure 1. The differences of Shanon-Weiner Diversity Index (H'), Shannon Evenness Index (E') dan Margelef Index ( $\mathrm{R}^{\prime}$ ) for Braconidae which is collected from Bukit Larut Perak (BL), Cameron Highland Pahang $(\mathrm{CH})$ and Gunung Ledang Johor (GL) according to the height

There was no significantly difference in the number of individuals of Braconidae between sites ( $\mathrm{F}=$ $0.38, \mathrm{df}=2 \& 30, \mathrm{P}<0.05)$ and between levels $(\mathrm{F}$ $=2.17, \mathrm{df}=1 \& 30, \mathrm{P}<0.05)$ (Table 3). However, there was a significant $(\mathrm{F}=3.78$, df $=2 \& 1, \mathrm{P}<$ 0.034 ) interaction between sites and levels per site.
This indicates that the diversity of braconids is influenced by the these two factors rather alone. Therefore, to study and understand the diversity of braconid in these highlands we must do sampling at both upper and lower portion of the highland.

Table 3. Result of Two-way ANOVA test for number of individual of Braconidae in three study sites (highlands)

\begin{tabular}{lccccc}
\hline Source & DF & SS & MS & F & P \\
\hline Sites & 2 & 1.1667 & 0.58333 & 0.38 & 0.690 \\
Level & 1 & 3.3611 & 3.36111 & 2.17 & 0.151 \\
Sites x level & 2 & 11.7222 & 5.86111 & 3.78 & 0.034 \\
Error & 30 & 46.5000 & 1.5500 & & \\
Total & 35 & 62.7500 & & & \\
\hline
\end{tabular}

\section{CONCLUSION}

Result of this study support our hypothesis that there are differences in abundance and diversity of braconid between these three highlands. Interestingly, we were able to prove that Cameron Highland $(\mathrm{CH})$ is more likely to have been disturbed more than that of Bukit Larut (BL), by looking at the result of individuals of Braconidae collected. The degree of disturbances in $\mathrm{CH}$ is significantly higher in upper level of this highland than in the lower level. This is evidenced by active illegal land clearing for the vegetables and flower growing plus some improper planning of infrastructure development. 


\section{ACKNOWLEDGEMENTS}

Special thanks to Mr. Ruslan Md Yusop and Mr. Fauzi Muzammil for their assistance and cooperation in making the project completed. This study was partially funded by the MOSTI grants number 05-01-02-SF0194.

\section{REFERENCES}

1. Askew, R. R. 1973. Parasitic Insects. London: Heinemann Educational Books Ltd.

2. Askew, R. R. \& Shaw, M. R. 1986. Parasitoid communities: Their size, structure and development. In Waage, J. \& Greathead, D. (edit.) Insect Parasitoids. London: Academic Press. 225- 259 pp.

3. Azmariah, M. 2001. Flora Lumut Sejati (Musci) di Bukit Larut, Perak, Malaysia. Master Thesis. Faculty of Science adn Technology, Universiti Kebangsaan Malaysia. Not Published.

4. Forman, R. T. 1995. Land Mosaics: The Ecology of Landscapes and Regions. Cambridges University Press, Cambridge, England. 1- 25 pp.

5. Gauld, I. D. 1984. An Introduction to the Ichneumonidae of Australia with a contribution on Metopiinae by M. G. Fitton. British Museum of Natural History, London. 155- 161 pp.

6. Gauld, I. D. 1986. Longitudinal gradients in ichneumonid species-richness in Australia. Ecology of Entomology 11: 155161.

7. Goulet, H. \& Huber, J. T. 1993. Hymenoptera of the world: An identification guide to families. Canada: Research branch agriculture Canada. 1300 pp.

8. Idris A. B., Hainidiah, J. 2003. Diversity of Ichneumonid wasps in the logged over forests of Langat Basin in Selangor,
Malaysia. Online Journal of Biological Sciences 3 (2): 259- 270

9. Kim, K. C. 1993. Biodiversity, conservation and inventory: why insect matter. Biodiversity of Conservation 2: 191-214

10. Latiff, A. M. 2010. Personal interview. Universiti Kebangsaan Malaysia.

11. May, R. M. 1975. Stability and Complexity in Model Ecosystems. Princeton: Princeton University Press.

12. Pielou, E. C. 1975. Ecological Diversity. New York: John Wiley and Sons. 165 pp.

13. Sharkey, M. J. 1993a. Family Braconidae. In Goulet, H. \& Huber, J. T. (edit.). Hymenoptera of the World: An Identification Guide to Families. Ottawa Canada: Agriculture Canada Publishing. 362-395 pp.

14. Sharkey, M. J. 1993b. Hymenoptera of the world. An identification guide to families. Agriculture Canada Publishing. 3:362395.

15. Szujecki, A. 1987. Ecology of Forest Insects. Poland: Polish Scientific Publishers.

16. Townes, H. 1972. A Light-weight Malaise Traps. Entomology News 83: 239-247 